
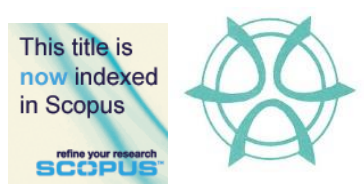

PLANNING MALAYSIA:

Journal of the Malaysian Institute of Planners

SPECIAL ISSUE V (2016), Page 157 - 168

\title{
SYNTHESISING AN EFFECTIVE INCENTIVES SYSTEM IN SAFEGUARDING THE HERITAGE VILLAGE OF MELAKA AND GEORGE TOWN
}

\author{
Indera Syahrul Mat Radzuan ${ }^{1} \&$ Yahaya Ahmad ${ }^{2}$ \\ ${ }^{1}$ Department of Real Estate Management \\ Faculty of Technology Management \& Business \\ UNIVERSITI TUN HUSSEIN ONN MALAYSIA \\ ${ }^{2}$ Centre for Building, Construction \& Tropical Architecture \\ Faculty of Built Environment \\ UNIVERSITY OF MALAYA
}

\begin{abstract}
This paper summarizes the main findings derived from the field study held in three heritage villages located in the proximity of Melaka and George Town city. This study has employed a mixed method approach by using a questionnaire survey on the residents and interviews involving officials and local village leaders of the Morten Village and the Chitty Village in Melaka as well as the Clan Jetty Village in George Town. This study was conducted to address an overarching question, which is whether incentives programme that have been formulated for the community are suitable for their aspirations and needs. This paper analyses the residents' perception on the effectiveness of the current incentives policy by using Bennett's programme evaluation method. It evaluates the findings in relation to the present policy framework for understanding and managing the cultural heritage incentives programme in order to establish the sustainable community in the heritage village. As observed, this study has identified some constraints such as low quality of the conservation works and lack of incentives provision from the viewpoints of the local residents. In dealing with the efficiency of the current incentives programme, this study has taken the stance that a policy formulation for the incentives programme should visually reflect the 'real' needs of the local communities.
\end{abstract}

Keyword: cultural heritage, incentives system, heritage village, case study. 
Indera Syahrul Mat Radzuan \& Yahaya Ahmad

Synthesising an Effective Incentives System in Safeguarding the Heritage Village of Melaka and George Town

\section{INTRODUCTION}

In Malaysia, the cities of Melaka and George Town have played a major role in enhancing the living multicultural heritage, as depicted by its various religious and cultural practices of the society. The living cultural heritage in these cities were reinforced by the existence of the early urban settlements that have come to symbolise the unique multi-ethnic vestiges of the formation of the nation and which need to be continuously conserved and preserved. However, in recent decades the historic settlements in Malaysia were found to face adverse influences of modernization (Kamarul S. Kamal et al., 2007; and Amran Hamzah $\&$ Rosli Noor, 2006). The major changes in the historic settlements can be traced back from the last three decades due to industrialization, rapid urbanisation and economic growth of the country. The rapid economic development has caused the future demolitions of some historic districts in order to make way for new development and this has resulted in an alteration of the socio-economic landscape and unsettling communities imbalances. This paper syntheses the main findings derived from the field study held in three heritage villages located in the proximity of Melaka and George Town city that have been able to reflect the essence of the multi-cultures of the Malaysian society.

\section{SAFEGUARDING SYSTEM AND POLICY}

Malaysia is a federal constitutional elective monarchy with three-tier system of government. In managing the heritage properties, there are the Federal Government, the State Government and the Local Authorities, with the different roles and approaches on the preservation and conservation work for the identified monuments and buildings. A number of ministries and agencies at the federal, state and local levels are involved in the promotion, management and conservation of heritage buildings and areas.

At the federal level, under the Ministry of Tourism and Culture, is the Department of National Heritage which operates under the provisions of the National Heritage Act (2005) enacted in order to preserve the national heritages of the country. Other related ministries in the federal level are the Ministry of Housing \& Local Government, the Ministry of Works, the Ministry of Education and the non-government agencies or organisations such as the Badan Warisan Malaysia. The State Executive Council (Exco), Municipal Council, State Tourism Action Council, State Town \& Country Planning Department and Heritage Trust are the state agencies which were tasked to administer and manage the conservation of heritage sites at the state level. The local governments including the local authorities such as the George Town World Heritage Incorporated (GTWHI), Melaka World Heritage Office (MWHO), the Think City Sdn. Bhd and the Melaka Museums Corporation (PERZIM) play a role by executing the by-laws, standards and practices for the management and promotion of the heritage buildings and sites. 


\section{METHODOLOGY}

Following the case study approach by Yin (2003) and Stake (1995), this research study represents an appropriate method for inquiry into the emergent and diverse components of the community development in Melaka. In this regard, a mixed methods approach of concurrent triangulation designs was employed by performing document reviews, observations, structured interviews and a questionnaire survey involving residents in the two heritage villages in Melaka. These methods consisted of two distinct approaches: quantitative and qualitative (Creswell, Clark, Clark, Gutmann \& Hanson, 2003). In their design, the researcher would collect both quantitative and qualitative data concurrently and would then compare the two databases to determine if there could be a convergence, differences, or some combination (Creswell, 2009). Thus, with this quantitative data and their qualitative analysis, a study could refine and explain those statistical results by exploring the participants' views in more depth (Creswell, 2003; Rossman \& Wilson, 1985; and Tashakkori \& Teddlie, 1998).

In order to fully understand the dynamics of the incentives system, this study has employed a mixed method approach by using a questionnaire survey on the residents and interviews involving officials and local village leaders of the Morten Village and the Chitty Village in Melaka as well as the Clan Jetty Village in George Town. A two-stage cluster sampling was selected to filter the optimal respondents, who had found to be benefited from the incentives provided by the authorities. The survey data were collected from March to April 2014. Survey questionnaires were held with 103 households, including 45 from Morten Village, 18 from Chitty Village and 40 from Clan Jetty Village (Table 1).

Table 1: Demographic profile of the Morten, Chitty and Clan Jetty Villages

\begin{tabular}{llll}
\hline Demographic Profile & Morten & Chitty & Clan Jetty \\
\hline Population & 630 & 255 & 950 \\
Number of households & 98 & 23 & 150 \\
Total area & 12 acre & 4 acres & 16.8 acre \\
Number of incentive recipients & 80 & None & None \\
Number of samples & 45 & 18 & 40 \\
\hline
\end{tabular}

For the survey, the researcher visited the selected homes of the respondents and explained the purpose of the study. Each interview lasted approximately 30 minutes to 1.5 hours. Respondents were asked about the types of incentives they had received, their perceptions on the effectiveness of the current incentives policy and their real needs for the cultural heritage conservation. Mean and ANOVA test were used to identify the different perceptions of the incentives programmes' evaluation by the residents and their real needs in the study areas. 
Indera Syahrul Mat Radzuan \& Yahaya Ahmad

Synthesising an Effective Incentives System in Safeguarding the Heritage Village of Melaka and George Town

The selection of the respondents was based on the following criteria: (i) residents who had benefited from the heritage incentives from the authorities, and (ii) residents who were residing permanently at the settlements. The samples were filtered based on the screening questions, whether or not they have had ever received any incentives or financial support from the authorities with regards to the conservation of their cultural heritage. To attain a holistic view, 35 interviews were carried out with groups of specialists (including academicians and conservators), cultural reference groups (including community leaders, heritage managers, cultural groups, the private sector and NGOs).

It is also important to note that these traditional villages are located in a vicinity of the core and buffer zones of Malaysia's historic towns of Melaka and George Town which were inscribed by UNESCO under serial nomination as the cultural sites known as the Historic Cities of the Straits of Malacca in 2008. The selection of these three villages was based on a fact that the Morten, Clan Jetty and Chitty Villages represent the unique traditional settlements of the three major races of the country which is the Malay, Chinese and Indian respectively (Figure $1)$.

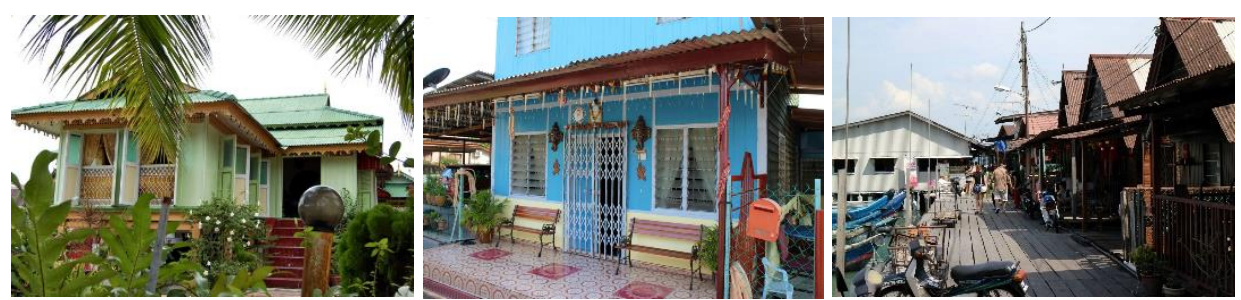

Figure 1: Typical traditional houses in Morten Village, Chitty Village and Clan Jetty Village

Source: Author (2014)

\section{THE INCENTIVES SYSTEM AND ITS ROLE}

In the context of the cultural heritage conservation, policy-makers in developed and developing nations are becoming more aware of the importance of identifying the best incentives mechanism or tool for the preservation of their cultural heritage in the historic areas. Incentive of cultural heritage protection has made reference to funding pattern, resource allocation, financial control mechanisms, the quality of financial information, performance management and prioritization (Klein, 2000). However, as yet, there has been little or no research into the nature and impact of these incentives and how they might be integrated into the heritage management strategies. Much literatures have encompassed the incentives provision in diverse disciplines such as researched in finance by Read (2005), wildlife conservation by Hadlock and Beckwith (2002), forest management by Kumar (2007), business by Goetz (2010) but very few researchers have touches on heritage areas. 
Roddewig (1987), has been one of the few commentators who has written explicitly about the use of incentives in the preservation of historic areas. $\mathrm{He}$ pointed out how some of the ways in which incentives can assist the conservation of historical areas. In his view, incentives have two specific roles in the conservation process: (1) to generate more rehabilitation of historic structures than would be possible, presumably, through other forms of government action, and (2) to provide a reasonable economic return to owners of buildings protected and restricted by laws.

\section{RESULTS AND ANALYSIS}

In this study, numerous incentives programmes have been created with either financial or non-financial means by the Malaysian government to help in preserving the heritage villages. At the three selected sites, $97 \%$ of the respondents in Morten have reported that the house received financial incentives from the authorities. However, respondents in the Chitty and Clan Jetty Villages received incentives in the form of infrastructure development.

\section{Morten Village}

Situated in the heart of Melaka city, the Morten Village has over 600 residents and was named after the British Land Commisioner, F. J. Morten (Wee, 1999). In the Morten Village, about RM2 million has since been allocated by the Federal Government, via the Ministry of Culture, Arts and Tourism (recently known as the Ministry of Tourism and Culture) in order for them to standardise the roofing of more than 80 houses in 2000. Besides that, the beautification programmes had been carried out so as to enhance its aesthetic appeal. The most significant aid was for house renovation where selected old Malay houses have undergone renovation mainly to its main structure, walls, windows, roofs and stairs. This allocation was administered by the Melaka Museums Corporation using the funding allocated by the Conservation and Restoration Trust Fund from 2001 to 2010.

Obviously, the restoration project benefitted the recipient house owners. A majority of them received financial support, RM10,000 each with total allocations approximately RM100,000 in 2001. The highest sum distributed in 2010 and 2008 amounted to RM64,550.00 and RM46,500.00 respectively. Other aesthetic efforts provided by the Government consisted of the improvements of the pedestrian walkways beautification, tree planting along the river and streets, outdoor street lamps, installation of roof lamp, landscape, signage, the arch gate and other public utilities. As part of revitalizing the landscape efforts by the Melaka Historic City Council (MBMB), steel railings with attractive designs were erected along the facade facing the Melaka River for the safety of the villagers and visitors. 
Indera Syahrul Mat Radzuan \& Yahaya Ahmad

Synthesising an Effective Incentives System in Safeguarding the Heritage Village of Melaka and George Town

\section{Chitty Village}

On the other hand, the Chitty Village is a home for over 200 residents who call themselves the 'Chitty' or Hindu Peranakan. According to Moorthy (2009) 'Chitty' means merchant in the Tamil language. This village has also received funds from the government to upgrade their tourist's facilities in 2009 (Table 2). The total value of the financial support was RM499,350.00. The grants were used particularly to upgrade the performance hall, outdoor street lamp installations, village road maintenance and drainage repairs and they were completed in 2010. In order to ensure the sustainability of the intangible heritage, in 2011 Melaka Museums Corporation (PERZIM) has also allocated RM20,000 to the Chitty communities to set up and train cultural troupes comprising the local youths (UNESCO, 2011).

Table 2: Supporting funds for upgrading tourist's facilities in the Chitty Village in 2009

\begin{tabular}{lc}
\hline Project & Total cost (RM) \\
\hline $\begin{array}{l}\text { To upgrade the performance hall, outdoor street lamp } \\
\text { installations, village road maintenance and drainage repairs }\end{array}$ & $449,350.00$ \\
\hline
\end{tabular}

\section{Clan Jetty Village}

The Clan Jetty Village that spreads along the waterfront of Weld Quay in George Town city, represents a unique settlement by Chinese immigrants who share common historical, geographical and lineage origin (Hockston \& Tan, 2011). The Clan Jetty Village is the timber jetty housing numbering over 800 populations which remains as the George Towns's waterfront communities mainly the Chinese community.

Clan Jetties are built with wood on wooden stilts. Consequently, many structures are now weak and require regular repairs and maintenance. Recently, it was reported that RM300,000 had been spent by the state authority on repairing the walkways in the Chew Jetty and RM150,00 for the Lee Jetty (Table 3). As observed by the researcher, the basic utilities such as water supply and electricity were supplied to them with fire hose reels and street lamps installed in the common areas.

Table 3: Total allocations for the repairs of planked walkways by the Penang State Government

\begin{tabular}{lc}
\hline \multicolumn{1}{c}{ Type of repairs } & Total cost (RM) \\
\hline Replacement of half of the total walkways in Chew Jetty & $300,000.00$ \\
Repairs on the damaged walkways in Lee Jetty & $150,000.00$ \\
\hline Source: Author (2014)
\end{tabular}

The data of the survey were analysed using the Statistical Package for the Social Sciences (SPSS) Version 20.0. Its analyses the residents' perception on the 
effectiveness of the current incentives policy by using Bennett's programme evaluation method (Bennett \& Rockwell, 2004). Bennett's has came up with the hierarchy that could show the causal links between the steps from inputs to outcomes and where along the continuum of change an extension programme has reached its delivery. It evaluates the findings in relation to the present policy framework for understanding and managing the cultural heritage incentives programme in order to establish the sustainable community in the heritage village. By using the five-point Likert scale, respondents were asked whether they agreed or disagreed with the statements pertaining to their satisfaction or dissatisfaction towards the incentives programme's inputs (how participants perceive the resources of the programme), programme's activities (how participants react to the events or activities conducted), programme's participation (the extent to which participants were involved), programme's reactions (how participants react to the programme's interest), programme's learning (the extent to which participants acquired knowledge), programme's actions (how participants react to the decision taken) and programme's impact (the overall benefits).

Table 4 shows a summary of the mean scores of the incentives programme evaluation by the residents of the three heritage villages. For the Morten Village, the mean scores ranged from 2.73 to 3.95, with an overall mean of 3.53. Among the seven factors of the incentives programme's evaluations, programme's participation and programme's inputs had the highest mean score with a value of 3.95 and 3.89 respectively, followed by the programme's actions (3.66) the programme's reactions (3.51), the programme's learning (3.50), the programme's activities (3.44), and the programme's impact (2.73).

Table 4: Mean scores for the incentives programme evaluation of Morten, Chetty and Clan Jetty

\begin{tabular}{lllc}
\hline $\begin{array}{l}\text { Incentives } \\
\text { Programmes } \\
\text { Evaluation }\end{array}$ & $\begin{array}{l}\text { Morten } \\
\text { (Mean) }\end{array}$ & $\begin{array}{l}\text { Case Study } \\
\text { Chetty } \\
\text { (Mean) }\end{array}$ & $\begin{array}{c}\text { Clan Jetty } \\
\text { (Mean) }\end{array}$ \\
\hline Inputs & 3.8889 & 3.4444 & 2.9083 \\
Activities & 3.4356 & 3.2000 & 2.8550 \\
Participation & 3.9481 & 3.5926 & 3.0333 \\
Reactions & 3.5111 & 3.3889 & 2.8000 \\
Learning & 3.4963 & 3.2037 & 2.9500 \\
Actions & 3.6593 & 3.3704 & 2.9250 \\
Impacts & 2.7333 & 2.8056 & 2.9000 \\
\hline Total Mean & 3.5247 & 3.2865 & 2.9102 \\
\hline
\end{tabular}

Source: Author (2014)

For the Chitty Village, the mean score value ranged from 2.81 to 3.59 , with an overall mean score at a moderate 3.29. The highest mean score for the incentives programme's evaluation in the Chitty Village was for the programme's 
Indera Syahrul Mat Radzuan \& Yahaya Ahmad

Synthesising an Effective Incentives System in Safeguarding the Heritage Village of Melaka and George Town

participation with an average of 3.59 , followed closely by the programme's inputs (3.44), the programme's reactions (3.39), the programme's actions (3.37), the programme's learning (3.20), the programme's activities (3.20), and the programme's impact (2.81). The results have demonstrated that the incentives programme in these two villages had been accorded some degrees of commitment. However, continuous improvement by the authorities should be focused more on the programme's impact which scored the lowest.

As for the Clan Jetty Village, the overall mean score was the lowest as compared to the mean scores of the Morten and Chitty villages with the mean value at 2.91. Of this village, the highest mean score for the incentives programme evaluation was for the programme's participation with an average of 3.03 , followed by the others with an average mean score below 3.00 point for example the programme's learning (2.95), the programme's actions (2.93), the programme's inputs (2.91), the programme's impacts (2.90), the programme's activities (2.86), and the programme's reactions (2.80). The next part of the analysis of this study involved the ANOVA test analysis for the entire incentives programme evaluation by the residents of the three villages (Table 5).

The ANOVA test was carried out in order to identify the differences in perception towards the programme's inputs, programme's activities, programme's participation, programme's reactions, programme's learning, programme's actions, programme's impact, and the overall perception towards the incentives programme amongst residents in the Morten, Chitty and Clan Jetty Villages. It is apparent from Table 6 that there was a statitically significant difference in their perception of the programme's inputs, programme's activities, programme's participation, programme's reactions and programme's actions and the overall perception towards the incentives programme amongst residents in the Morten, Chitty and Clan Jetty Villages. However, the ANOVA showed that the programme's learning and programme's impacts results were not statistically significantly different.

Table 5: Summary of Levene's Test and ANOVA of the Morten, Chetty and Clan Jetty

\begin{tabular}{llccc}
\hline Program's Evaluation & $\begin{array}{c}\boldsymbol{p} \text {-value } \\
\text { (Levene's Test) }\end{array}$ & $\begin{array}{c}\text { Assumption of } \\
\text { Homogeneity of } \\
\text { Variances }\end{array}$ & $\begin{array}{c}\boldsymbol{p} \text {-value } \\
\text { (ANOVA) }\end{array}$ & $\begin{array}{c}\text { Significant } \\
\text { Difference }\end{array}$ \\
\hline Programme's Inputs & 0.572 & Yes & 0.000 & Yes \\
Programme's Activities & 0.040 (Welch) & No & 0.031 & Yes \\
Programme's Participation & 0.080 & Yes & 0.000 & Yes \\
Programme's Reactions & 0.225 & Yes & 0.010 & Yes \\
Programme's Learning & $0.058($ Welch) & Yes & 0.054 & No \\
Programme's Actions & 0.213 & Yes & 0.004 & Yes \\
Programme's Impacts & 0.783 (Welch) & Yes & 0.798 & No \\
\hline Overall & 0.216 & Yes & 0.006 & Yes \\
\hline
\end{tabular}


PLANNING MALAYSIA:

Sustainable Urban Development

Post-hoc comparisons using the Tukey HSD test have indicated that only the Morten and Clan Jetty Villages were significantly different from one another at the $p<0.05$ level. The study found apparent differences for the programme evaluation with the programme's inputs, activities, participation, reactions and actions. The residents' perception towards the five significantly different variables in Morten was found to be greater than that from the Clan Jetty Village. The actual difference found in the perception towards the programme's inputs, activities and participation between the two study areas (Morten and Clan Jetty) was small, based on Eta squared (below 0.01). Meanwhile, the magnitude of the difference in the means of perception towards the programme's reactions and actions were found to be moderate with Eta squared value of 0.09 and 0.11 respectively.

\section{DISCUSSIONS}

This study was undertaken in order to evaluate how the incentives programme has worked and what were the impacts and challenges faced by the concerned communities in the current scenario. The following evidences have been recorded by the researcher after listening to the authorities and villagers' voices. With rapid urbanization, one respondent from the Morten Village stated that: "The government has undertaken conservation measures since 2000 in order to preserve the traditional houses. Initially, many of the houses have been repaired and the new roofs were installed with the help of the government budget for restoration projects. But it was centrally controlled. Yet we had no say in it. And after fifteen years have passed, why now there are no more proactive actions taken by the government to support and maintain our heritage village?" (Personal communication, March 12, 2014).

Furthermore, one respondent has pointed out that: "Appointed contractors installed the new roofs, timber walls and windows for our properties. However, the quality of the workmanship is found to be poor. For instance, after they had finished the renovation, we again faced other problems such as some roofs were leaking; there were gaps in between the timber wall arrangement, the windows they installed did not fit and could not be closed easily. The poor workmanship is really unacceptable and we are not truly satisfied because they did everything in a hurry. The contractors ignored our feedback about their workmanship" (Personal communication, March 17, 2014). Another respondent commented that: "The materials that they used were of a low quality. Some of the timber planks used were recycled and had been used before. They just fitted them for the sake of the repairs. Even for the floors, the planks they used were not planed and not smooth. I've to cover them up with mats" (Personal communication, March 18, 2014). These results are likely to be related to the residents' concerns on the lack of monitoring system led by the authorities in the implementation phase. 
Indera Syahrul Mat Radzuan \& Yahaya Ahmad

Synthesising an Effective Incentives System in Safeguarding the Heritage Village of Melaka and George Town

However, responses from the officers in local authority thus revealed a lack of creativities among the locals in promoting their own cultural heritage programme. R3, an officer in Melaka commented: "State government have conducted numerous workshop and programmes to educate the local communities for the past few years. However, the communities need to be more self-reliance and proactive to establish their own heritage programme rather than heavily rely on the government funds and support. The communities itself must be creative enough to promote their own uniqueness" (Personal communication, March 21, 2014). For R2, an officer in the Federal department suggested that there is a need for the local communities in the heritage village to establish their own heritage programme due to lack of financial resources from the government. He added that: "Government can't afford to conserve and protect all houses within the heritage village. We have to consider the cultural and architectural significance in order to provide the support" (Personal communication, March 17, 2014).

Moreover, one of the residents in the Chitty Village has pointed out that: "[...] what concerns me most is that the government is not doing enough to protect our land from the urbanization pressure. Our land here used to be a playground for children enjoying our traditional games such as 'congkak', 'galah panjang', 'ketenteng', 'gasing', 'layang-layang', 'guli' and 'batu seremban'. This is the place where we grew up with laughter and joy. What has happened now is really disappointing. Our village is surrounded by 'urban jungles'. Nature is disappearing fast" (Personal communication, March 15, 2014). The reason for this was clear and perhaps may have something to do with their disappointment on fragility of their custom and traditional lifestyles which seems to be threatened.

The researcher also recorded the Clan Jetty Village residents' views on the incentive programme in their village. As pointed out in the previous section, this village has been given some allocations by the state government in order to improve the walkaways, installation of the fire extinguishers and the street lamps. Despite these improvements, one respondent in Clan Jetty Village has expressed his disappointment: "No improvement in our quality of life. Government only provides us with walkaways, no incentives were given to repair our houses. I think it's about time for the government to help us preserve this historic village", (Personal communication, April 6, 2014). It can thus be suggested that the authorities should provide adequate financial supports to safeguard the dilapidated houses so as to maintain its significance value of intangible heritage of the communities. 


\section{CONCLUSION}

The researcher had discovered and learnt from this first insightful study of the three heritage villages the importance of the effectiveness of the incentives programme in guiding the conservation efforts for the local community. As observed, this study has identified some constraints on the current incentives policy implementation from the viewpoints of the local residents. Further studies regarding the role and impacts of incentives provision would be interesting to explore particularly in the case of community-based research. In dealing with the efficiency of the current incentives programme, this study has taken the stance that a policy formulation for the incentives programme should visually reflect the 'real' needs of the local communities.

\section{ACKNOWLEDGEMENTS}

We would like to express our sincere thanks to all the respondents and professionals in the selected organisations who patiently responded to our questions. This study would not have been possible without support by the Ministry of Higher Education Malaysia, University of Malaya (Project No. PV110-2012A) and the Universiti Tun Hussein Onn Malaysia (UTHM).

\section{REFERENCES}

Amran Hamzah \& Rosli Noor. (2006). Is Melaka ready for World Heritage Listing. Malaysian Town Plan, 3(1), 5-18.

Bennett, C. \& Rockwell, K. (2004). Targeting outcomes of programs: a hierarchy for targeting outcomes and evaluating their achievement. Faculty Publications: Agricultural Leadership, Education \& Communication Department. University of Nebraska - Lincoln. Paper 48.

Creswell, J.W. (2003). Research Design: Qualitative, Quantitative and Mixed Methods Approaches (2nd ed.). Thousand Oaks, CA: Sage.

Creswell, J. W. (2009). Research Design: Qualitative, Quantitative and Mixed Methods Approaches (3rd ed.). Thousand Oaks, CA: Sage.

Creswell, J.W., Clark, P., Clark, V.L.P., Gutmann, M.L. \& Hanson, W.E. (2003). Advanced mixed methods research design. In A. Tashakkori \& C. Teddlie (Eds.), Handbook of Mixed Methods in Social \& Behavioral Research (209240). Thousand Oaks, CA: Sage.

Goetz, K.S. (2010). Encouraging sustainable business, practices using incentives: A practitioner's view. Management Research Review, 33(11), 1043-1053.

Hadlock, T.D. \& Beckwith, J.A. (2002). Providing incentives for endangered species recovery. Human Dimensions of Wildlife, 7(3), 197-213.

Hockston, K. \& Tan, H. (2011). Penang: An Inside Guide to its Historical Homes, Buildings, Monuments and Parks. Penang: Studio Howard.

Kamarul S. Kamal, Lilawati A. Wahab \& A. Ghafar Ahmad. (2007). Conservation issues in the colonial built heritage of Malacca, Malaysia. Paper presented at the 5 th 
Indera Syahrul Mat Radzuan \& Yahaya Ahmad

Synthesising an Effective Incentives System in Safeguarding the Heritage Village of Melaka and George Town

International Conference on Science \& Technology in Archaeology \& Conservation. July 7-11, Granada-Baeza Spain.

Klein, R. (2000). The New Politics of the NHS (4th ed.). London: Prentice Hall.

Kumar, C. (2007). Perceptions of incentives for participation: insights from joint forest management in India. International Journal of Sustainable Development \& World Ecology, 14(5), 532-542.

National Heritage Act 2005 (Act 645) (Malaysia).

Moorthy, R. (2009). The evolution of the Chitty community of Melaka. Jebat: Malaysian Journal of History, Politics and Strategic Studies, 36, 1-15.

Read, D. (2005). Monetary incentives, what are they good for? Journal of Economic Methodology, 12(2), 265-276.

Roddewig, R.J. (1987). Economic Incentives for Historic Preservation. Washington D.C.: National Trust for Historic Preservation, Centre for Preservation Policy Studies.

Rossman, G.B. \& Wilson, B.L. (1985). Numbers and words: Combining quantitative and qualitative methods in a single large-scale evaluation study. Evaluation Review, 9(5), 627-643.

Stake, R.E. (1995). The Art of Case Study Research. Thousand Oaks, CA: Sage Publications.

Tashakkori, A. \& Teddlie, C. (1998). Mixed Methodology: Combining Qualitative and Quantitative Approaches. Thousand Oaks, CA: Sage.

UNESCO (2011). Report on the Implementation of the Action Plan of Melaka, Malaysia. In Cultural Heritage Management and Tourism: Models for Co-operation among Stakeholders. Case Study: Melaka Historic City, Malaysia. Paper presented at the UNESCO-Norway Cultural Heritage and Tourism Project 2001, October 818, Lijiang, China.

Wee, B. (1999). Village where time stands still. New Straits Times: Heritage. pp 22.

Yin, R.K. (2003). Case Study Research: Design and Methods. Thousand Oaks, CA: Sage Publications. 